\title{
PREVALENCE OF PERIPHERAL ARTERIAL DISEASE AMONG HEMODIALYSIS PATIENTS
}

\author{
By
Tarek Ebrahim Ahmed Abo Al-Fadl*, Mohamed Salah El-Feshawy**, Hany Ismail Hamed* and Ahmed Alaa El-Din Ahmed M. Saad*

Departments of *Internal Medicine and **Diagnostic Radiology, Faculty of Medicine, AlAzhar University

Corresponding author: Tarek Ebrahim Ahmed Abo Al-Fadl

E-mail: tarekibrahim858@gmail.com

\begin{abstract}
Background: Peripheral arterial disease (PAD) is common in patients with end-stage renal disease on hemodialysis, but is frequently underdiagnosed. The risk factors for PAD are well known within the general population, but they differ somewhat in hemodialysis patients. This study aimed to determine the prevalence of PAD and its risk factors in patients on hemodialysis.
\end{abstract}

Objective: To assess the prevalence of peripheral arterial disease in end stage renal disease patients on hemodialysis.

Patients and Methods: This was across-sectional study carried out at Hemodialysis Unit of Al-Hussein University Hospital over a period of six month; from September 2019 to April 2020, and conducted on 80 hemodialysis patients. Demographic data and clinical information were recorded. Laboratory data including CBC, calcium, phosphate, total cholesterol, triglyceride, high-density lipoprotein, and iron profile were evaluated. The ankle-brachial index was measured in all patients. PAD was diagnosed if ankle-brachial index $<0.9$. Duplex ultrasound for arterial system of both lower limb was done for patient with ankle / brachial index $>0.9$.

Results: As regard description of demographic data, the mean age of all studied patients was $45.3 \pm 8.8$ years with minimum age of 24 years and maximum age of 62 years. There were 43 males (53.8\%) and 37 females (46.3\%). Thirty-five patients (43.7\%) were diabetic, and 48 patients $(60 \%)$ were hypertensive. According to laboratory profile, the mean of WBCs, Hb, platelets, serum calcium, PO4, and iPTH were $6.5 \times 10^{3} / \mathrm{ul}, 10.4$ $\mathrm{g} / \mathrm{dl}, 228.2 \times 10^{3} / \mathrm{ul}, 8.3 \mathrm{mg} / \mathrm{dl}, 9.4 \mathrm{mg} / \mathrm{dl}$ and $477.2 \mathrm{ug} / \mathrm{ml}$ respectively. Regarding lipid profile, the mean of total cholesterol, HDL and triglyceride were $214.7 \mathrm{mg} / \mathrm{dL}, 41.9 \mathrm{mg} / \mathrm{dL}$, and $172.2 \mathrm{mg} / \mathrm{dL}$, respectively. Regarding to iron profile, the mean of iron serum, ferritin and TIBC were $62.7 \mathrm{mg} / \mathrm{dl}, 603.3 \mathrm{ng} / \mathrm{ml}$ and 236.7 $\mathrm{mg} / \mathrm{dl}$, respectively. According to ABI, there were 22 patients $(27.5 \%) \leq 0.9$, while there were 58 patients $(72.5 \%)>0.9$. The prevalence of peripheral arterial disease among HD patients was $27.5 \%$.

Conclusions: High prevalence of peripheral arterial disease in CKD patients on hemodialysis and Ankle brachial index was clearly more sensitive than physical examination in detecting of peripheral arterial disease in CKD patients on hemodialysis.

Key words: Peripheral arterial disease among hemodialysis Patients, ankle brachial index.

\section{INTRODUCTION}

Peripheral arterial disease (PAD) of the lower extremities is widespread, and it affects over 200 million people worldwide. The prevalence of PAD has increased over the last decade, particularly in low-income countries (Fowkes et al., 2017). It is also highly prevalent among patients with end-stage renal disease, and 
it has serious consequences that influence patient outcomes (Viazzi et al., 2017). PAD increases with age and is $4.5-14.5 \%$ more prevalent among individuals aged $\geq 65$ years (Criqui and Aboyans, 2015). Chronic kidney disease (CKD) is a global public health problem with a rising prevalence. Low glomerular filtration rate is associated with higher risk for kidney failure requiring dialysis, as well as with cardiovascular disease (CVD), hypertension, anemia, and other metabolic Complications (Abdel-Hady et al., 2013). Cardiovascular disease is still the most common cause of morbidity and mortality in hemodialysis patients (Monfared et al., 2013). Lower-extremity peripheral artery disease (PAD) affects approximately 10 million adults in the United States and more than 200 million adults throughout the world. Its global prevalence has increased by $24 \%$ from 2000 to 2010 (Benjamin et al., 2019). PAD is associated with an increased risk for other cardiovascular diseases such as myocardial infarction and stroke, reduces quality of life, and is a leading cause of nontraumatic leg amputation (Fowkes et al., 2013). However, it is initially asymptomatic, and it can only be diagnosed through screening tests, the ankle-brachial index (ABI) being the one used most frequently (Aboyans et al., 2012). Among patients on hemodialysis (HD), the prevalence of PAD is much higher, ranging from 17 to $48 \%$ (Garimealla and Hirsch, 2014). Therefore, many patients on HD with PAD could avoid or at least delay adverse events, such as amputations, cardiovascular events, and death if PAD was timely diagnosed and adequately treated (Matsuzawa et al., 2015).
Although these studies were valuable, they had different methods for PAD diagnosis. The early diagnosis and management of PAD can improve the prognosis for patients on HD (Ogata et al., 2010).

The present work aimed to assess the prevalence of peripheral arterial disease among hemodialysis patients.

\section{PATIENTS AND METHODS}

This cross-sectional study included 80 hemodialysis patients at Nephrology Unit Al Hussein University Hospital from September 2019 to April 2020. Written informed consent obtained from the patients for all procedures that performed. All procedures followed Al-Azhar University Ethical Committee Regulation.

All patients received 3 hemodialysis sessions weekly.

\section{Inclusion Criteria:}

1. Patient's age between 18 and 60 years.

2. Duration of hemodialysis more than 6 months.

3. Uses of native arteriovenous fistula in all patients.

\section{Exclusion Criteria:}

1. Patients less than 18 years or more than 60 years.

2. Duration of hemodialysis less than 6 months.

3. Un controlled hypertension or diabetes mellitus.

4. Recent infection.

5. Known to be collagen disease.

6. Diagnosis of PAD based on ankle / brachial index. 


\section{All Patients in this study were subjected to the following:}

1. History and clinical examination stressing on ischemic symptoms.

2. Laboratory Investigations (Serum Creatinine - serum Calcium - serum phosphorus - intact parathyroid hormone - serum iron - serum ferritin - transferrin saturation - lipid profile.

3. Ankle / brachial index measured by Doppler ultrasound.
4. Duplex ultrasound for arterial system of both lower limb for patient with ankle / brachial index $>0.9$ will be done.

Statistical analysis of data was done by using Statistical Program for Social Science (SPSS) version 24. Quantitative data were expressed as mean \pm standard deviation (SD). Qualitative data were expressed as frequency and percentage.

\section{RESULTS}

As regard description of demographic data, the mean age of all studied patients was $45.3 \pm 8.8$ years with minimum age of 24 years and maximum age of 62 years.
There were 43 males $(53.8 \%)$ and 37 females $(46.3 \%)$. Thirty five patients $(43.7 \%)$ were diabetic, and 48 patients (60\%) were hypertensive (Table 1).

\section{Table (1): Demographic data of studied patients}

\begin{tabular}{|c|c|c|c|}
\hline \multicolumn{2}{|c|}{ Variables } & \multicolumn{2}{c|}{$\begin{array}{c}\text { Studied patients } \\
\text { (N=80) }\end{array}$} \\
\hline \multirow{2}{*}{ Age (years) } & Mean \pm SD & \multicolumn{2}{c|}{$45.3 \pm 8.8$} \\
\cline { 2 - 4 } & Min - Max & \multicolumn{2}{c|}{$24-62$} \\
\hline \multirow{2}{*}{ Sex } & Males & 43 & $53.8 \%$ \\
\cline { 2 - 4 } & Females & 37 & $46.2 \%$ \\
\hline \multirow{2}{*}{ DM } & No & 45 & $56.3 \%$ \\
\cline { 2 - 4 } & Yes & 35 & $43.7 \%$ \\
\hline \multirow{2}{*}{ HTN } & No & 32 & $40 \%$ \\
\cline { 2 - 4 } & Yes & 48 & $60 \%$ \\
\hline
\end{tabular}

According to laboratory profile, the mean of WBCs, $\mathrm{Hb}$, platelets, serum calcium, PO4, and iPTH were $6.5 \times 10^{3} / \mathrm{ul}$, $10.4 \mathrm{~g} / \mathrm{dl}, 228.2 \times 10^{3} / \mathrm{ul}, 8.3 \mathrm{mg} / \mathrm{dl}, 9.4$ $\mathrm{mg} / \mathrm{dl}$ and $477.2 \mathrm{ug} / \mathrm{ml}$ respectively. Regarding lipid profile, the mean of total cholesterol, HDL and triglyceride were $214.7 \mathrm{mg} / \mathrm{dL}, 41.9 \mathrm{mg} / \mathrm{dL}, 172.2 \mathrm{mg} / \mathrm{dL}$, respectively. Regarding to iron profile, the mean of iron serum, ferritin and TIBC were $62.7 \mathrm{mg} / \mathrm{dl}, 603.3 \mathrm{ng} / \mathrm{ml}$ and 236.7 $\mathrm{mg} / \mathrm{dl}$, respectively (Table 2). 
Table (2): Laboratory profiles in studied patients

\begin{tabular}{|c|c|c|}
\hline \multicolumn{2}{|c|}{ Variables } & $\begin{array}{c}\text { Studied patients } \\
(\mathbf{N}=\mathbf{8 0})\end{array}$ \\
\hline \multirow{2}{*}{ Iron $(\mathbf{m g} / \mathbf{d l})$} & Mean \pm SD & $62.7 \pm 24.3$ \\
\cline { 2 - 3 } & Min - Max & $28-169$ \\
\hline \multirow{2}{*}{ Ferritin $(\mathbf{n g} / \mathbf{m l})$} & Mean \pm SD & $603.3 \pm 778.3$ \\
\cline { 2 - 3 } & Min - Max & $15-5558$ \\
\hline \multirow{2}{*}{ TIBC $(\mathbf{m g} / \mathbf{d l})$} & Mean \pm SD & $236.7 \pm 778.3$ \\
\cline { 2 - 3 } & Min - Max & $44-555$ \\
\hline \multirow{2}{*}{ T. CHOL $(\mathbf{m g} / \mathbf{d l})$} & Mean \pm SD & $214.7 \pm 50.4$ \\
\cline { 2 - 3 } & Min - Max & $146-388$ \\
\hline \multirow{2}{*}{ T.G $(\mathbf{m g} / \mathbf{d l})$} & Mean \pm SD & $172.2 \pm 48.3$ \\
\cline { 2 - 3 } & Min - Max & $122-321$ \\
\hline \multirow{2}{*}{ HDL $(\mathbf{m g} / \mathbf{d l})$} & Mean \pm SD & $41.9 \pm 5.9$ \\
\cline { 2 - 3 } & Min - Max & $30-56$ \\
\hline \multirow{2}{*}{ CA $(\mathbf{m g} / \mathbf{d l})$} & Mean \pm SD & $8.3 \pm 1.2$ \\
\cline { 2 - 3 } & Min - Max & $4.5-14$ \\
\hline \multirow{2}{*}{ PO4 $(\mathbf{m g} / \mathbf{m l})$} & Mean \pm SD & $5.4 \pm 1.8$ \\
\cline { 2 - 3 } & Min - Max & $2-9.9$ \\
\hline \multirow{2}{*}{ PTH $(\mathbf{u g} / \mathbf{m l})$} & Mean \pm SD & $477.2 \pm 476.7$ \\
\cline { 2 - 3 } & Min - Max & $12-2087$ \\
\hline
\end{tabular}

According to ABI, there were 22 patients $(27.5 \%) \leq 0.9$, while there were 58 patients $(72.5 \%)>0.9$ (Table 3).

Table (3): Ankle brachial index in all studied patients

\begin{tabular}{|c|c|c|}
\hline $\begin{array}{c}\text { Ankle brachial index } \\
\text { Studied Patients (N=80) }\end{array}$ & Index $\leq \mathbf{0 . 9}$ & Index $>\mathbf{0 . 9}$ \\
\hline $\mathbf{N}(\boldsymbol{\%})$ & $22(27.5 \%)$ & $58(72.5 \%)$ \\
\hline Mean $\mathbf{+ S D}$ & $0.83 \pm 0.07$ & $1.12 \pm 0.08$ \\
\hline Min - Max & $0.7-0.9$ & $1-1.3$ \\
\hline
\end{tabular}

According to duplex result, the prevalence of Peripheral arterial disease among HD patients was $27.5 \%$ (Table 4).

Table (4): Duplex results in all studied patients

\begin{tabular}{|c|c|c|}
\hline Duplex & \multicolumn{2}{|c|}{$\begin{array}{c}\text { Studied patients } \\
(\mathbf{N}=\mathbf{8 0})\end{array}$} \\
\hline Ischemia & 22 & $27.5 \%$ \\
\hline No ischemia & 58 & $72.5 \%$ \\
\hline
\end{tabular}

\section{DISCUSSION}

This study was carried out at Hemodialysis Unit of Al-Hussein University Hospital over a period of six month; from September 2019 to April
2020, and conducted on 80 Hemodialysis Patients.

As regard description of demographic data, the mean age of all studied patients was $45.3 \pm 8.8$ years with minimum age of 
24 years and maximum age of 62 years. There were 43 males $(53.8 \%)$ and 37 females $(46.3 \%)$. Thirty five patients $(43.7 \%)$ were diabetic and 48 patients (60\%) were hypertensive. Regarding pretreatment laboratory profile, results showed that the mean of WBCs, $\mathrm{Hb}$, platelets, serum calcium, $\mathrm{PO} 4$, and $\mathrm{iPTH}$ were $6.5 \times 10^{3} / \mathrm{ul}, 10.4 \mathrm{~g} / \mathrm{dl}, 228.2 \times 10^{3} / \mathrm{ul}$, $8.3 \mathrm{mg} / \mathrm{dl}, 9.4 \mathrm{mg} / \mathrm{dl}$ and $477.2 \mathrm{ug} / \mathrm{ml}$ respectively. Regarding lipid profile, results showed that the mean of total cholesterol, HDL and triglyceride were $214.7 \mathrm{mg} / \mathrm{dL}, 41.9 \mathrm{mg} / \mathrm{dL}, 172.2 \mathrm{mg} / \mathrm{dL}$, respectively.

Regarding iron profile, results showed that the mean of iron serum, ferritin and TIBC were $62.7 \mathrm{mg} / \mathrm{dl}, 603.3 \mathrm{ng} / \mathrm{ml}$ and $236.7 \mathrm{mg} / \mathrm{dl}$, respectively.

Regarding results of $\mathrm{ABI}$, there were 22 patients $(27.5 \%) \leq 0.9$, while there were 58 patients $(72.5 \%)>0.9$. The prevalence of Peripheral arterial disease among HD patients was $27.5 \%$.

The results of current study were supported by Laghari et al. (2015) in which a total of $72 \mathrm{CKD}$ patients were included. The age of the patients ranged from 18 to 75 years, with a mean of 53.22 years. Of all the patients, 46 patients $(63.9 \%)$ were male and 26 patients $(36.1 \%)$ were female. Twenty-five patients $(34.7 \%)$ were in stage $3 \mathrm{CKD}$ with a GFR of $30-60 \mathrm{~mL} / \mathrm{min}, 27.8 \%$ were in stage 4 CKD with a GFR of 15 $30 \mathrm{~mL} / \mathrm{min}$ and 27 patients $(37.5 \%)$ were in stage 5 CKD with a GFR of $<15$ $\mathrm{mL} / \mathrm{min}$; of these patients, 25 (34.7\%) were on hemodialysis. Twenty patients (27.8\%) had an ABI < 0.9 and hence had PVD. In accordance with our results Arroyo et al. (2017) in a large multicenter cohort enrolled 2445 CKD subjects in 81 Spanish hospitals and dialysis clinics, 559 controls with an MDRD > 60 $\mathrm{mL} / \mathrm{min} / 1.73 \mathrm{~m} 2$ were recruited from nine primary care centers from different regions of the country. The mean age of the CKD population was 57.9612 .8 years, and $61.7 \%$ were male patients. Prevalence of hypertension, dyslipidemias and diabetes were 89.3, 64.9 and $25.7 \%$, respectively. CKD patients had a higher prevalence of subclinical PAD than nonCKD controls $(28.0 \%$ versus $12.3 \%, \mathrm{P}<$ 0.00 .

PAD is a regular complication of hemodialysis patients and is associated with poor outcomes. However, it is initially asymptomatic, and it can only be diagnosed through screening tests, the ankle-brachial index (ABI) being the one used most frequently (Aboyans et al., 2012).

\section{CONCLUSION}

High prevalence of peripheral arterial disease in CKD patients on hemodialysis and Ankle-brachial index was clearly more sensitive than physical examination in detecting of peripheral arterial disease in CKD patients on hemodialysis.

\section{REFERENCES}

1. Abdel-Hady H, Khamis S, Salah Y, Elbarbary H, Zahir E and Elmahmoudy A (2013): Fibroblast growth factor 23 as a risk factor of left ventricular hypertrophy and vascular calcification in predialysis chronic kidney disease patients. Menoufia Med J, 26:717.

2. Aboyans V, Criqui $M H$ and Abraham $P$ (2012): Measurement and interpretation of the ankle-brachial index: a scientific statement from the American Heart Association. Circulation, 126: 2890-2909. 
3. Arroyo D, Betriu A and Valls J (2017): Factors influencing pathological ankle-brachial index values along the chronic kidney disease spectrum: The NEFRONA study. Nephrol Dial Transplant., 32: 513-520.

4. Benjamin EJ, Muntner $P$ and Alonso A (2019): Heart disease and stroke statistics2019 update: a report from the American Heart Association. Circulation, 139(10): e56-e528.

5. Criqui MH and Aboyans V (2015): Epidemiology of peripheral artery disease. Circ Res., 116(9):1509-26.

6. Fowkes FGR, Aboyans V and Fowkes FJI (2017): Peripheral artery disease: epidemiology and global perspectives. Nat Rev Cardiol., 14(3):156-70.

7. Fowkes FGR, Rudan D and Rudan I (2013): Comparison of global estimates of prevalence and risk factors for peripheral artery disease in 2000 and 2010: a systematic review and analysis. Lancet, 382(9901):1329-40.

8. Garimella PS and Hirsch AT (2014): Peripheral artery disease and chronic kidney disease: clinical synergy to improve outcomes. Adv Chronic Dis., 21(6):460-71.

9. Laghari S, Ullah K, Masroor I, Butt G and Kifayat F (2015): Prevalence of peripheral arterial disease diagnosed by ankle brachial index among chronic kidney disease patients in a tertiary care unit. Saudi Journal of Kidney Diseases and. Transplantation, 26(5):924-13.

10. Matsuzawa R, Aoyama $\mathbf{N}$ and Yoshida A (2015): Clinical characteristics of patients on hemodialysis with peripheral arterial disease. Angiology, 66(10):911-7.

11. Monfared, A., Salari, A., Kazemnezhad, E., Lebadi, M., Khosravi, M., Mehrjardi, N. K. and Amini, N. (2013): Association of left ventricular hypertrophy with high-sensitive Creactive protein in hemodialysis patients. International Urology and Nephrology, 45(6): 1679-1686.

12. Ogata H, Kumata-Maeta $C$ and Shishido $K$ (2010): Detection of peripheral artery disease by duplex ultrasonography among hemodialysis patients. Clin J Am Soc Nephrol., 5(12):2199-206.

13. Viazzi F, Leoncini G, Ratto E, Storace G, Gonnella A and Garneri D (2017): Peripheral artery disease and blood pressure profile abnormalities in hemodialysis patients. $\mathbf{J}$ Nephrol., 30(3):427-33. 


\section{معدل إنتشار أمر اض الثر ايين الطرفية في المرضي المعاثنين علي الاستصفاء الدموي}

طارق إبراهيم أحمد ابو الفضل*، محمد صلاح الفيثاوي **، هاني إسماعيل حامد*، الفي أحمد علاء الاين أحمد محمد سعد*

قسمي الأمراض الباطنة* و الأثعة التثخيصية***، كلية الطب، جامعة الأزهر

E-mail: tarekibrahim858@gmail.com

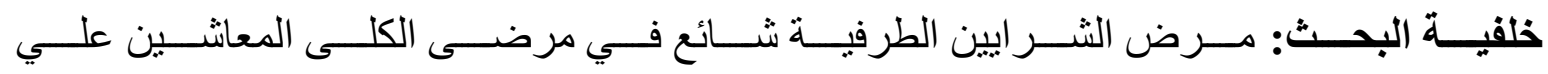

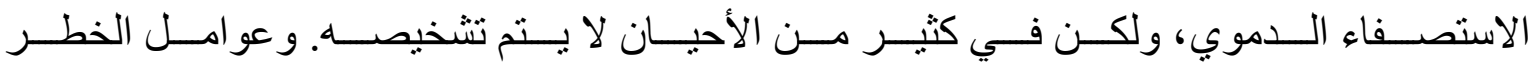

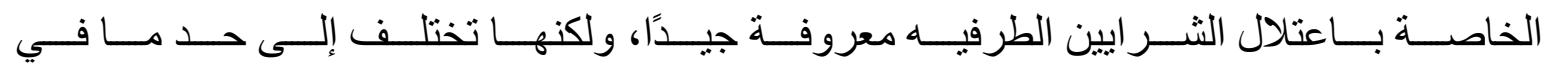
مرضى الكلى المعاثين علي الاستصفاء الدموي.

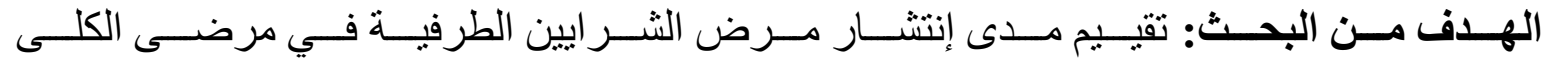

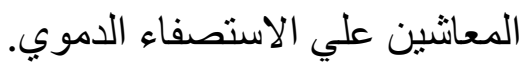

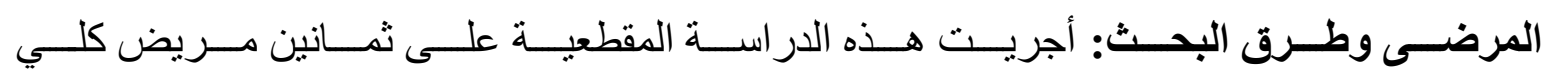

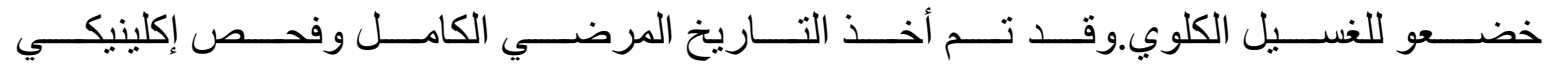

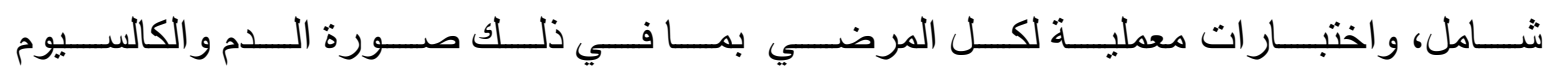

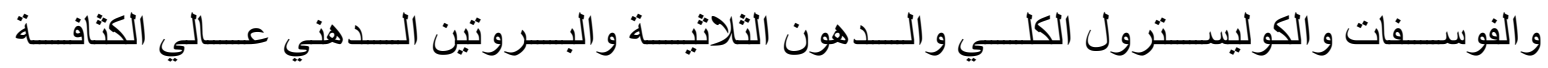

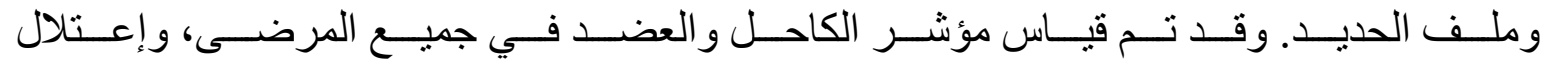

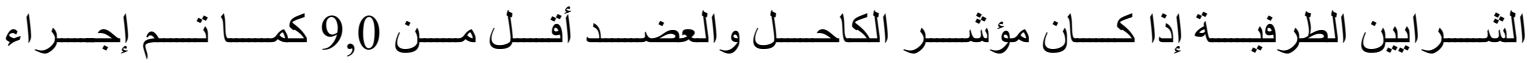

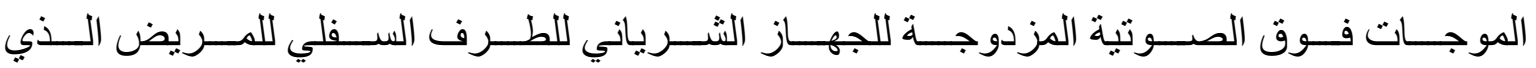
لايه مؤشر الكاحل/ العضد أكبر من 9,0.

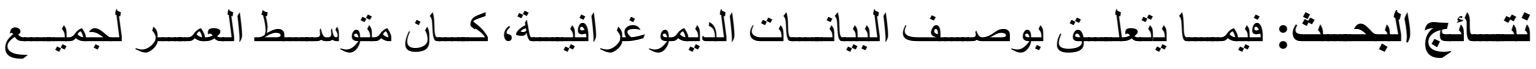

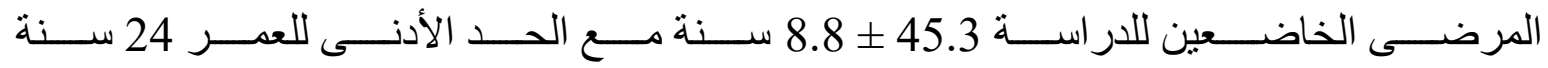

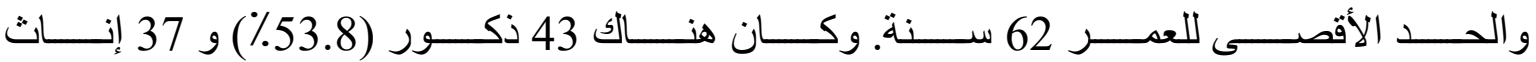

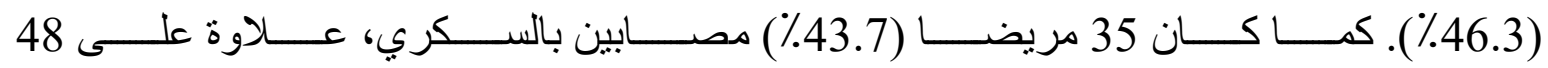

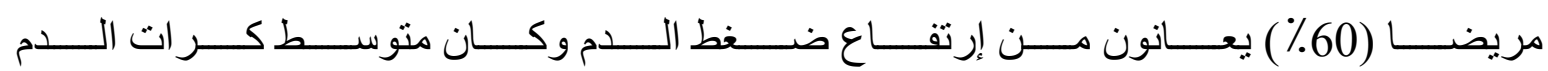

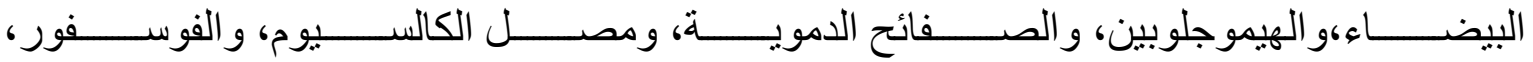




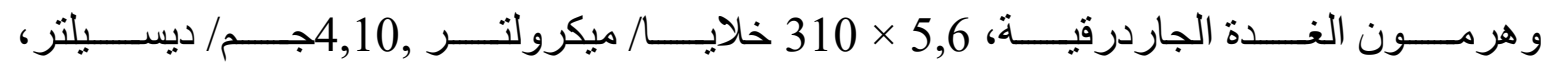

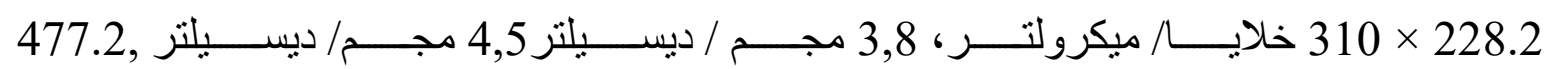

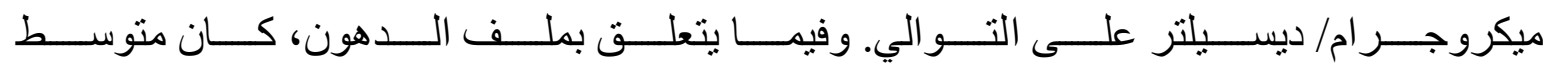

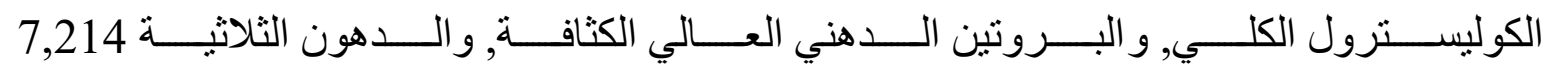

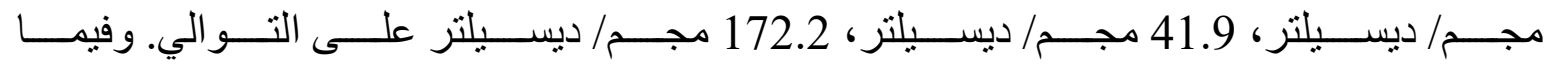

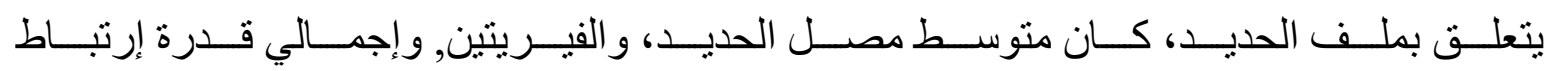

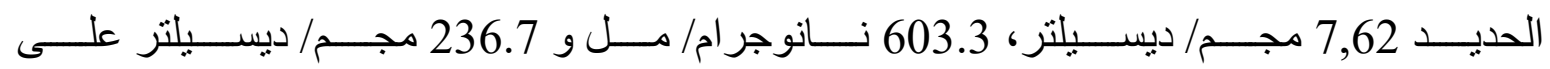

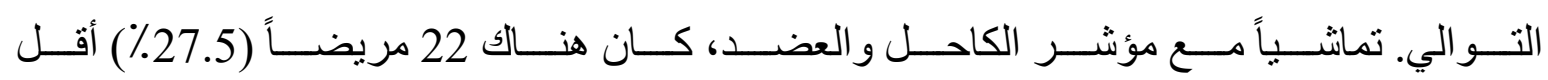

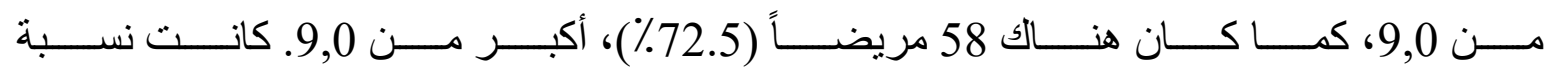

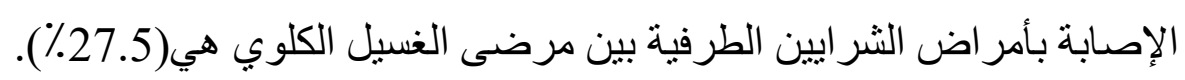

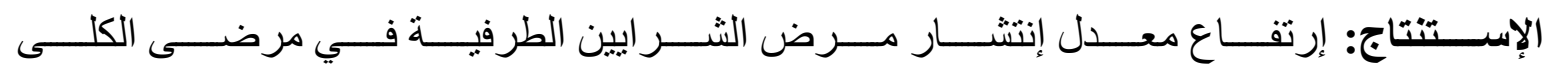

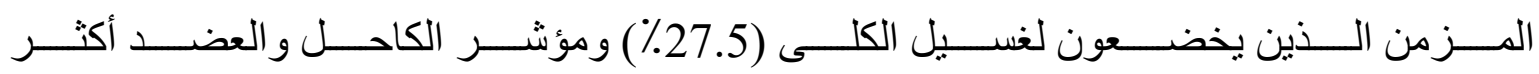

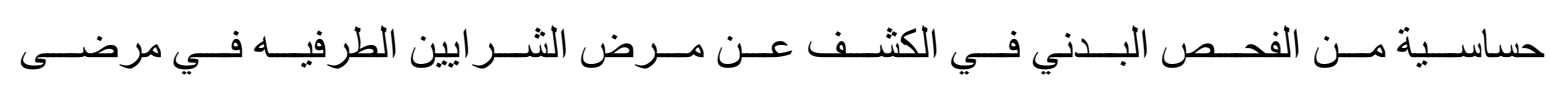
الكلى المزمن المعانثين علي الاستصفاء الدموي.

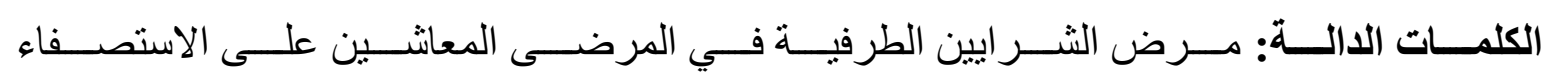
الاموي، مؤشر الكاحل و العضد. 